\title{
A SERIES OF LOW-ALTITUDE AERIAL RADIOLOGICAL SURVEYS OF SELECTED REGIONS WITHIN AREAS 3, 5, 8, 9, 11, 18, AND 25 AT THE NEVADA TEST SITE
}

\author{
SURVEY DATES \\ December 2 to 6, 1996 \\ July 24, 1997 \\ May 6 to 7, 1998 \\ June 16 to 19,1998 \\ June 1 to 16,1999
}

Approved for Public Release; Further Dissemination Unlimited. 


\section{DISCLAIMER}

This report was prepared as an account of work sponsored by an agency of the United States Government. Neither the United States Government nor an agency thereof, nor any of their employees, nor any of their contractors and subcontractors, or their employees, make a warranty, express or implied, or assumes legal liability or responsibility for the accuracy, completeness, or any third party's use or the results of such use of any disclosed information, apparatus, product, or process or represents that its use would not infringe privately owned rights. Reference herein to any specific commercial product, process, or service by trade name, trademark, manufacturer, or otherwise, does not necessarily constitute or imply an endorsement, recommendation, or favoring by the United States government or an agency thereof or its contractors or subcontractors. The views and opinions of the authors expressed herein do not necessarily state or reflect those of the United States Government or agencies thereof.

Available electronically at http://www.doe.gov/bridge

Available for sale to the public, in paper, from:

U.S. Department of Commerce

National Technical Information Service

5285 Port Royal Road

Springfield, VA 22161

phone: 800.553 .6847 or 703.605 .6000

fax: 703.605.6900

email: orders@ntis.fedworld.gov

online ordering: http://www.ntis.gov/ordering.htm

Available for a processing fee to U.S. Department of

Energy and its contractors, in paper, from:

U.S. Department of Energy

Office of Scientific and Technical Information

P.O. Box 62

Oak Ridge, TN 37831-0062

phone: 423.576 .8401

fax: 423.576 .5728

email: reports@adonis.osti.gov 


\section{A SERIES OF LOW-ALTITUDE AERIAL RADIOLOGICAL SURVEYS OF SELECTED REGIONS WITHIN AREAS 3, 5, 8, 9, 11, 18, AND 25 AT THE NEVADA TEST SITE}

\section{SURVEY DATES}

December 2 to 6, 1996

July 24, 1997

May 6 to 7, 1998

June 16 to 19,1998

June 1 to 16,1999

David Colton

Bechtel Nevada

REVIEWED BY

Alan J. Will, Manager

Remote Sensing and Applied Technology Department

Michael F. Mohar, Manager

Aerial Measuring System Project

Clifton M. Bluitt, Manager

Radiation Sciences Section 


\section{ABSTRACT}

A series of low-altitude, aerial radiological surveys of selected regions within Areas 3, 5, 8, 9, 11, 18, and 25 of the Nevada Test Site was conducted from December 1996 through June 1999. The surveys were conducted for the U.S. Department of Energy by the Remote Sensing Laboratory, located in Las Vegas, Nevada, and maintained and operated by Bechtel Nevada.

The flights were conducted at a nominal altitude of 15 meters above ground level along a set of parallel flight lines spaced 23 meters apart. The purpose of these low-altitude surveys was to measure, map, and define the areas of americium- 241 activity. The americium contamination will be used to determine the areas of plutonium contamination.

Americium-241 activity was detected within 8 of the 11 regions. The three regions where americium241 was not detected were in the inactive Nuclear Rocket Development Station complex in Area 25, which encompassed the Test Cell A and Test Cell C reactor test stands and the Reactor Maintenance Assembly and Disassembly facility. 


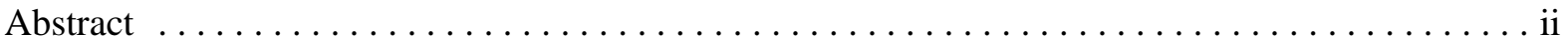

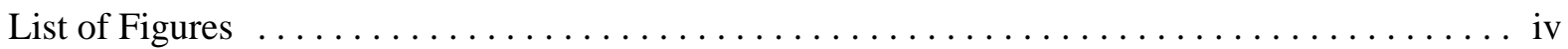

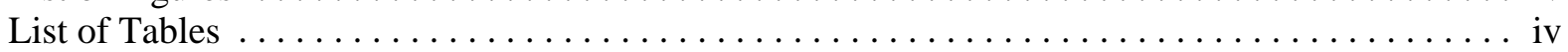

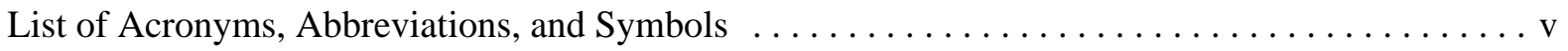

\section{Sections}

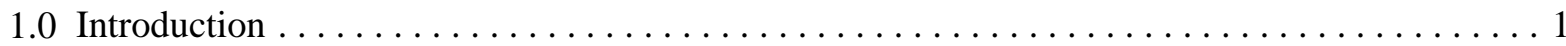

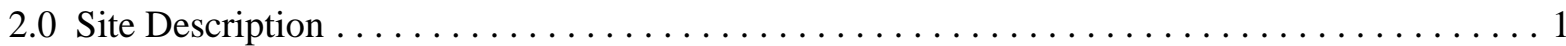

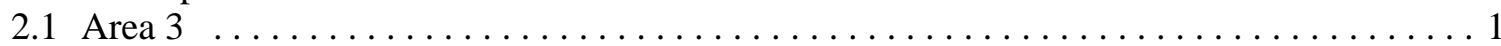

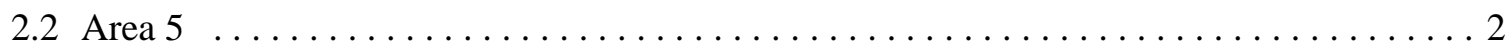

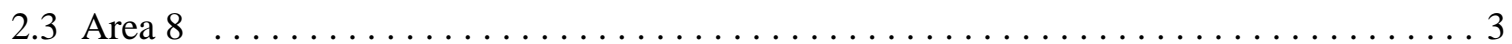

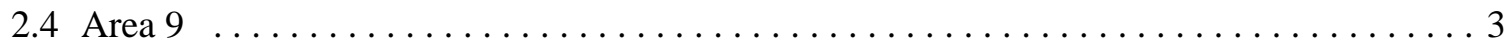

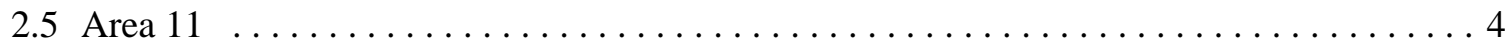

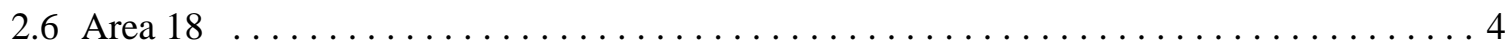

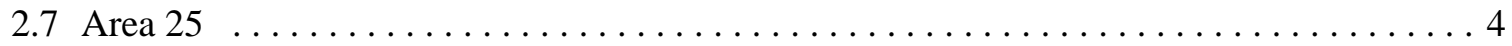

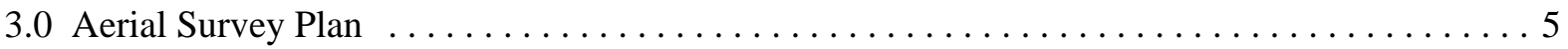

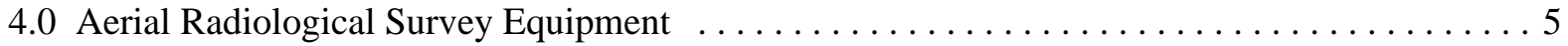

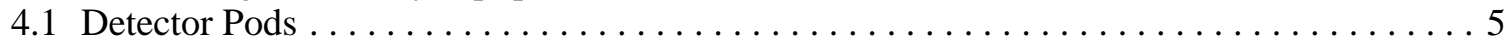

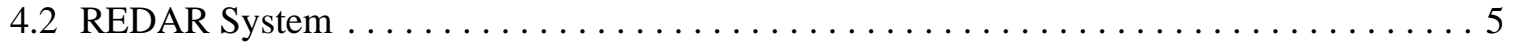

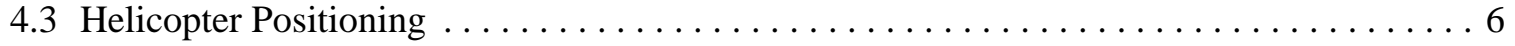

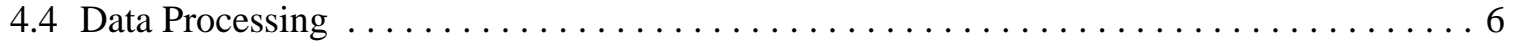

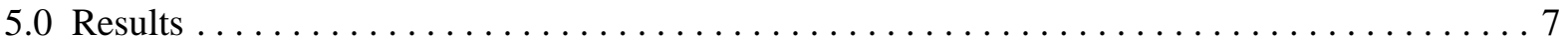

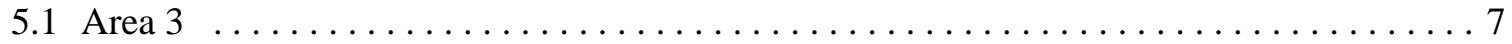

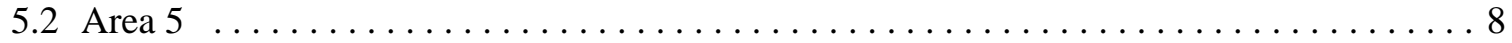

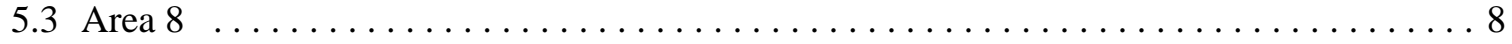

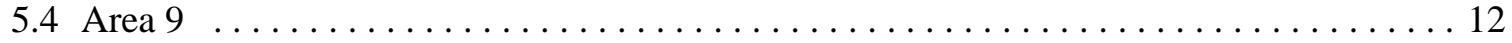

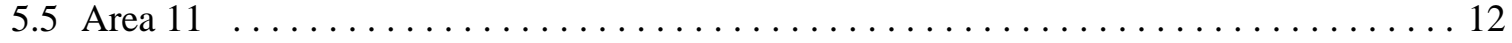

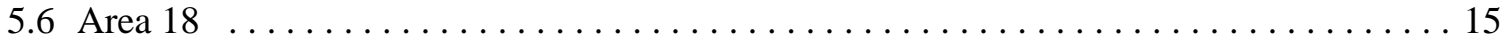

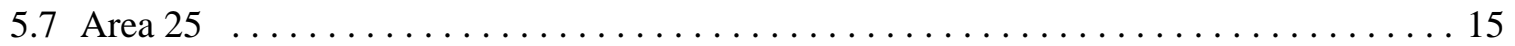

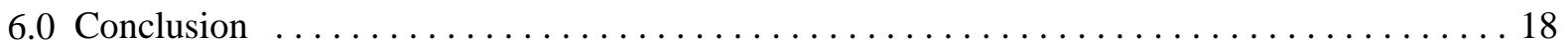

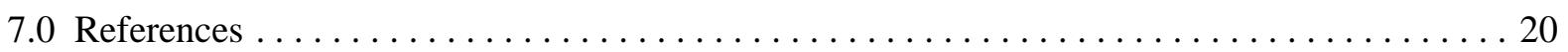

\section{Appendixes}

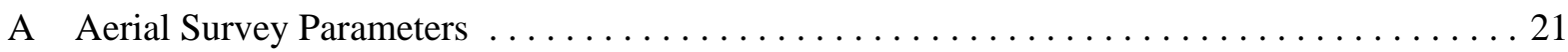

B Data Analysis Parameters . . . . . . . . . . . . . . . . . . . . . 23 


\section{LIST OF FIGURES}

1 Americium-241 Contour Map of the NTS Area $3 \ldots \ldots \ldots \ldots \ldots \ldots \ldots \ldots$

2 Americium-241 Contour Map of the GMX Project Area

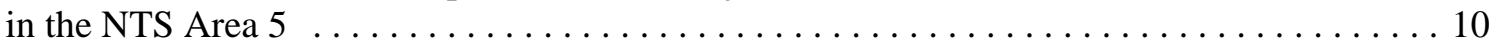

3 Americium-241 Contour Map of the NTS Area $8 \ldots \ldots \ldots \ldots \ldots \ldots \ldots \ldots \ldots \ldots$

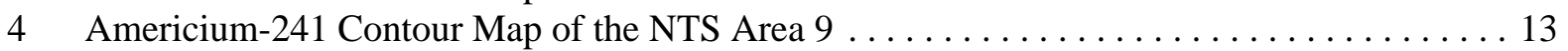

5 Americium-241 Contour Map of the Plutonium Valley

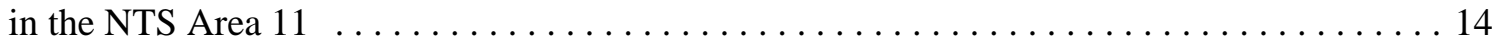

6 Americium-241 Contour Map of the Little Feller Sites

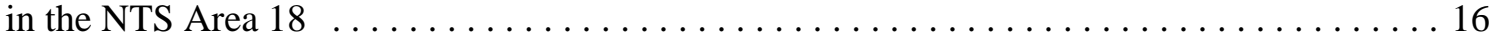

7 Americium-241 Contour Map of the Danny Boy Site

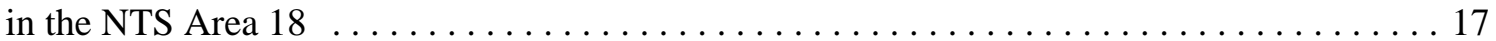

8 Man-Made Gross Count Contour Map of the NTS Area $25 \ldots \ldots \ldots \ldots \ldots \ldots \ldots \ldots$

\section{LIST OF TABLES}

1 Pseudo Coordinate Locations for the NTS 50-Foot AGL

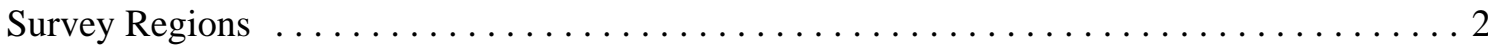




\section{LIST OF ACRONYMS, ABBREVIATIONS, AND SYMBOLS}

$\begin{array}{ll}\mu \mathrm{Ci} & \text { microcurie } \\ \mu \mathrm{Ci} / \mathrm{m}^{2} & \text { microcurie per square meter (a unit of radioactivity in surface soil) } \\ { }^{241} \mathrm{Am} & \text { americium-241 } \\ { }^{137} \mathrm{Cs} & \text { cesium-137 } \\ { }^{152} \mathrm{Eu} & \text { europium-152 } \\ { }^{22} \mathrm{Na} & \text { sodium-22 } \\ { }^{239} \mathrm{Pu} & \text { plutonium-239 } \\ { }^{240} \mathrm{Pu} & \text { plutonium-240 } \\ { }^{241} \mathrm{Pu} & \text { plutonium-241 } \\ \mathrm{AGL} & \text { above ground level } \\ \mathrm{cps} & \text { counts per second } \\ \mathrm{DOE} & \text { U.S. Department of Energy } \\ \mathrm{EMAD} & \text { Engine Maintenance Assembly and Disassembly (facility in Area 25) } \\ \mathrm{ETS} & \text { Engine Test Stand (facility in Area 25) } \\ \mathrm{ft} & \text { feet } \\ \mathrm{GPS} & \text { Global Positioning System } \\ \text { keV } & \text { kiloelectronvolts (unit of gamma-ray energy) } \\ \mathrm{km} & \text { kilometer } \\ \mathrm{m} & \text { meter } \\ \mathrm{m} / \mathrm{s} & \text { meters per second } \\ \mathrm{MBB} & \text { Messerschmitt-Bolkow-Blohm } \\ \text { MCA } & \text { multichannel analyzer } \\ \text { MDA } & \text { minimum detectable activity } \\ \text { MMGC } & \text { man-made gross count } \\ \text { NaI(Tl) } & \text { thallium-activated sodium iodide } \\ \text { NRDS } & \text { Nuclear Rocket Development Station (in Area 25) } \\ \text { NTS } & \text { Nevada Test Site } \\ \text { RDGPS } & \text { Real-Time Differential Global Positioning System } \\ \text { REDAR IV } & \text { Radiation and Environmental Data Acquisition and Recorder, Version IV } \\ \text { REDAR V } & \text { Radiation and Environmental Data Acquisition and Recorder, Version V } \\ \text { RMAD } & \text { Reactor Maintenance Assembly and Disassembly (facility in Area 25) } \\ \text { ROI } & \text { region of interest } \\ \text { RSL } & \text { Remote Sensing Laboratory } \\ \text { RWMS } & \text { Radioactive Waste Management Site (in Areas 3 and 5) } \\ & \end{array}$




\subsection{INTRODUCTION}

A series of low-altitude, aerial radiological surveys of selected regions within Areas 3, 5, 8, 9, 11, 18, and 25 of the Nevada Test Site (NTS) were conducted from December 1996 through June 1999. These surveys were conducted for the U.S. Department of Energy (DOE) by the Remote Sensing Laboratory (RSL), located in Las Vegas, Nevada, and maintained and operated for the DOE by Bechtel Nevada.

The purpose of the low-altitude surveys was to measure, map, and define the areas of americium-241 $\left({ }^{241} \mathrm{Am}\right)$ activity, and this information will be used to determine the areas of plutonium contamination. Since plutonium is a very weak gamma-ray emitter, the only practical way to determine the areas of plutonium activity in the environment by using gamma-ray spectroscopy is to measure a radionuclide closely associated with plutonium that can be easily detected by its gamma radiation emissions. The most abundant gamma ray related to plutonium is the 59.5-kiloelectronvolt $(\mathrm{keV})$ gamma ray from the decay of ${ }^{241} \mathrm{Am}$, which is a daughter product of plutonium-241 $\left({ }^{241} \mathrm{Pu}\right)$. Although the plutonium used in nuclear weapons is primarily ${ }^{239} \mathrm{Pu}$, the plutonium also contains traces of ${ }^{240} \mathrm{Pu}$ and ${ }^{241} \mathrm{Pu}$. By applying a suitable ratio of the activities of the plutonium isotopes (i.e., ${ }^{239} \mathrm{Pu}$ and ${ }^{240} \mathrm{Pu}$ ) to the measured ${ }^{241} \mathrm{Am}$ activity, estimates for the ${ }^{239} \mathrm{Pu}$ or ${ }^{240} \mathrm{Pu}$ activity and their locations can be derived.

The low-altitude, aerial survey regions presented in this report were chosen upon examination of an NTS site-wide aerial radiological survey ${ }^{1}$ that was conducted in 1994 using two helicopter-based systems. Table 1 shows a listing of the selected low-altitude, aerial survey regions and their pseudo coordinate locations.

\subsection{SITE DESCRIPTION}

This section contains a general description and history of the NTS areas where the low-altitude, aerial survey regions were located., ${ }^{2,3}$ A synopsis of the most probable nuclear weapons tests and/or safety experiments that may have contributed to any detected ${ }^{241} \mathrm{Am}$ or man-made activity is also presented.

\subsection{Area 3}

Area 3 is located near the center of the Yucca Flat weapons test basin. It was the site of 14 atmospheric tests conducted between 1952 and 1958. More than 250 underground nuclear tests were conducted in Area 3 from 1957 through 1992. This is the largest number of tests for any of the NTS underground testing areas. A number of these tests consisted of simultaneous detonations of nuclear devices, and nearly all of these tests consisted of single devices in separate emplacement holes. Nine of the underground nuclear tests in Area 3 were conducted in unstemmed holes to minimize, but not eliminate, the release of radioactivity to the atmosphere. These unique tests were conducted between mid-1957 and late 1958.

Also in this area is the Area 3 Radioactive Waste Management Site (RWMS) where bulk, low-level waste is being disposed and stored in selected subsidence craters. This activity commenced in the mid-1960s when the DOE began removing scrap tower steel, vehicles, and other large objects that had been subjected to atmospheric testing. From 1979 to 1990, large amounts of contaminated soil and other debris from the NTS were added to the craters. There are seven disposal craters. Two craters are in use, two are full and temporarily capped, and three are in reserve for potential future use.

The boundary of the low-altitude, aerial survey region in this area encompassed the Area 3 RWMS, the site of the Humboldt nuclear weapons-related test, the Pike nuclear weapons-related test, and the sites 


\section{Table 1. Pseudo Coordinate Locations for the NTS 50-Foot AGL Survey Regions}

\begin{tabular}{|c|c|c|c|}
\hline \multirow{2}{*}{$\begin{array}{l}\text { NTS } \\
\text { Area }\end{array}$} & \multirow{2}{*}{$\begin{array}{c}\text { Survey Region } \\
\text { (Primary Facility or Nuclear Test) }\end{array}$} & \multicolumn{2}{|c|}{$\begin{array}{l}\text { Pseudo Coordinates }{ }^{\mathrm{a}} \\
\text { (degrees-minutes-seconds) }\end{array}$} \\
\hline & & Latitude & Longitude \\
\hline 3 & $\begin{array}{l}\text { Area } 3 \text { RWMS } \\
\text { Nuclear tests: Chavez, Humboldt, } \\
\text { Otero, and Pike }\end{array}$ & $\mathrm{N} 37^{\circ} 02^{\prime} 48^{\prime \prime}$ & W $116^{\circ} 01^{\prime} 46^{\prime \prime}$ \\
\hline 5 & GMX Project Area & N $36^{\circ} 50^{\prime} 38^{\prime \prime}$ & W $115^{\circ} 56^{\prime} 06^{\prime \prime}$ \\
\hline 8 & Nuclear tests: Ceres, Oberon, and Titania & N $37^{\circ} 10^{\prime} 55^{\prime \prime}$ & W $116^{\circ} 04^{\prime} 09^{\prime \prime}$ \\
\hline 9 & $\begin{array}{l}\text { Nuclear tests: Juno, Mazama, } \\
\text { Post, and Vesta }\end{array}$ & N $37^{\circ} 07^{\prime} 22^{\prime \prime}$ & W $116^{\circ} 02^{\prime} 10^{\prime \prime}$ \\
\hline 11 & $\begin{array}{l}\text { Project } 56 \text { Numbers } 1,2,3 \text {, and four } \\
\text { (Plutonium Valley) }\end{array}$ & N $36^{\circ} 58^{\prime} 40^{\prime \prime}$ & W $115^{\circ} 57^{\prime} 30^{\prime \prime}$ \\
\hline 18 & Nuclear test: Danny Boy & $\mathrm{N} 37^{\circ} 06^{\prime} 39^{\prime \prime}$ & $\mathrm{W} 116^{\circ} 21^{\prime} 57^{\prime \prime}$ \\
\hline 18 & Nuclear test: Little Feller I & $\mathrm{N} 37^{\circ} 06^{\prime} 35^{\prime \prime}$ & W $116^{\circ} 19^{\prime} 05^{\prime \prime}$ \\
\hline 18 & Nuclear test: Little Feller II & N $37^{\circ} 07^{\prime} 09^{\prime \prime}$ & W $116^{\circ} 18^{\prime} 13^{\prime \prime}$ \\
\hline 25 & $\begin{array}{l}\text { Test Cell A (Nuclear Rocket Development } \\
\text { Station, NRDS) }\end{array}$ & N $36^{\circ} 49^{\prime} 44^{\prime \prime}$ & W $116^{\circ} 15^{\prime} 25^{\prime \prime}$ \\
\hline 25 & Test Cell C (NRDS) & N $36^{\circ} 49^{\prime} 51^{\prime \prime}$ & W $116^{\circ} 16^{\prime} 37^{\prime \prime}$ \\
\hline 25 & $\begin{array}{l}\text { Reactor Maintenance, Assembly, and } \\
\text { Disassembly (RMAD) facility }\end{array}$ & $\mathrm{N} 36^{\circ} 48^{\prime} 50^{\prime \prime}$ & W $116^{\circ} 14^{\prime} 06^{\prime \prime}$ \\
\hline
\end{tabular}

a Includes the averaged coordinates of all of the nuclear weapons tests and safety experiment sites cited for each survey region.

of the Chavez and Otero safety experiments. The Humboldt test was conducted in October 1958 and detonated a tower-mounted device that had a measured yield of 7.8 tons. The Pike test was conducted in March 1964 and detonated a device that was placed at the bottom of a drilled or mined vertical hole (shaft) and had a measured yield of less than 20 kilotons. The Chavez safety experiment was conducted in October 1958 and tested a tower-mounted device that had a measured yield of 0.6 tons. The Otero safety experiment was conducted in September 1958 and tested a device that was positioned at the bottom of a drilled or mined vertical hole and had a measured yield of 38 tons.

\subsection{Area 5}

This area is located in the southeastern portion of the NTS and includes the Area 5 RWMS, the Hazardous Waste Storage Unit, and the Hazardous Materials Spill Center. From 1951 through 1962, 14 atmospheric tests were conducted in Area 5, several of which were nuclear tests. Among the structural remains of the structures tested in Area 5 are simulated motel complexes, metal frames that supported a variety of roofing materials, a window test structure, cylindrical liquid storage vessels, reinforced concrete domes and aluminum domes, bridge pedestals, and a bank vault; all of these structural remains are of considerable historical interest. Five nuclear weapons-effects tests were 
conducted underground in Area 5 between 1965 and 1968. However, the presence of the carbonate aquifer made this area less suitable for underground testing than other locations on the NTS.

In the GMX Project Area, 24 experiments, some utilizing relatively small quantities of fissile materials, were conducted between 1954 and 1956. These experiments were "equation-of-state" studies where "instantaneous" changes in the physical properties of plutonium materials subjected to detonations from conventional explosives were measured. These experiments were conducted on or very near one place, and the source can be considered to be at one site. The boundary of the low-altitude, aerial survey region in this area only encompassed the GMX Project Area.

\subsection{Area 8}

This area is located in the northeast quadrant of the Yucca Flat weapons test basin. Area 8 was the site of four atmospheric nuclear tests conducted in 1958. From mid-1966 through late 1988, 10 underground nuclear tests were conducted at this location. Two of the underground tests involved the simultaneous firing of multiple devices put in the same emplacement hole. Underground shelter structures were tested in the late 1950s, and in 1964 these shelters were used by the University of Florida for shelter habitability studies.

The boundary of the low-altitude, aerial survey region in this area encompassed the sites of the Ceres, Oberon, and Titania safety experiments. The Ceres safety experiment was conducted in October 1958 and tested a tower-mounted device that had a measured yield of 0.7 tons. The Oberon safety experiment was conducted in October 1958 and tested a tower-mounted device. No measurable fission yield was reported. The Titania safety experiment was conducted in October 1958 and tested a tower-mounted device that had a measured yield of 0.2 tons.

\subsection{Area 9}

This area is located in the northeast quadrant of the Yucca Flat basin. Fifteen atmospheric tests were conducted in this area between 1951 and 1958. Area 9 has been used extensively for underground nuclear testing; 100 such tests were carried out from late 1961 to mid-1992. Of the dozen underground tests involving the simultaneous detonation of multiple devices, most involved the use of separate emplacement holes (two or more holes, each with a single device).

The Area 9 sanitary landfill is located in a subsidence crater formed as a result of a subsurface nuclear detonation in the early 1960s. This Class II landfill can receive all types of nonhazardous waste. In October 1995, the landfill underwent partial closure and will be reopened as a Class III construction and demolition debris landfill.

The boundary of the low-altitude, aerial survey region in this area encompassed the sites of the Mazama and Post nuclear weapons-related tests and the sites of the Juno and Vesta safety experiments. The Mazama nuclear weapons-related test was conducted in October 1958 and detonated a tower-mounted device. No yield resulting from the nuclear test could be measured. The Post nuclear weapons-related test was conducted in April 1955 and detonated a tower-mounted device that had a measured yield of 2 kilotons. The Juno safety experiment was conducted in October 1958 and tested a device that was placed on or close to the ground surface and had a measured yield of 1.7 tons. The Vesta safety experiment was conducted in October 1958 and tested a device that was placed on or close to the ground surface and had a measured yield of 24 tons. 


\subsection{Area 11}

This area is located along the eastern border of the NTS. Four aboveground safety experiments were conducted in the northern portion of Area 11 in 1955 and 1956 in what is now known as Plutonium Valley. Because of the radioactive residues that remain from the safety experiments, Area 11 continues to be used on an intermittent basis for realistic drills in radiological monitoring and sampling operations. In addition to the aboveground safety experiments, five underground nuclear weapons-effects tests were conducted in the southern portion of Area 11 between the spring of 1966 and 1971.

The boundary of the low-altitude, aerial survey region in this area encompassed all four sites of the safety experiments. All four safety experiments were designed to investigate whether fission would occur if a nuclear device were destroyed by conventional explosives. Each tested device was placed on or close to the ground surface. The first three experiments (Project 56, Numbers 1, 2, and 3) were conducted in November 1955 and reported no measurable fission yield. The fourth safety experiment (Project 56, Number 4) was conducted in January 1956 and reported a slight fission yield.

\subsection{Area 18}

This area is located in the northwest quadrant of the NTS. The inactive Pahute airstrip is located in the east-central portion of the area. When in operational status, the airstrip was primarily used for shipment of supplies and equipment for Pahute Mesa test operations.

Area 18 was the site of five nuclear weapons tests: four were conducted in 1962 and one was conducted in 1964. Two of the five were atmospheric tests, two were cratering experiments, and one was a stemmed, underground nuclear test. In 1964, the Lawrence Livermore National Laboratory used the area for a Plowshare-sponsored test using chemical high explosives to investigate the potential use of nuclear explosives for ditch digging in dense, hard rock.

Three separate, low-altitude, aerial survey regions were flown in this area. The boundaries of the first two survey regions encompassed the sites of the Little Feller I and II nuclear weapons-effects tests. The Little Feller I and II nuclear weapons-effects tests were conducted in July 1962. In both tests, a device was placed on or close to the ground surface, and a low-fission yield was measured at each site.

The boundary of the third survey region encompassed the site of the Danny Boy nuclear weapons-effects test. The Danny Boy test was conducted in March 1962 and detonated a device that was placed shallow enough underground to produce a crater by expelling the overlying soil when it was exploded. The Danny Boy test had a measured yield of 430 tons.

\subsection{Area 25}

This is the largest area and is located in the southwestern corner of the NTS. Located roughly in the center of Area 25, Jackass Flats was the site selected for a series of ground tests for reactors, engines, and rocket stages as part of a program to develop nuclear reactors for use in the nation's space program. In the early 1960s, the Atomic Energy Commission and the National Aeronautics and Space Administration negotiated an interagency agreement to establish and manage a test area at the NTS, designated as the NRDS. These facilities, inactive since 1973, remain today in various stages of dismantlement. They consist of three widely separated reactor test stands (i.e., Test Cell A, Test Cell C, and the ETS-1 Engine Test Stand); two maintenance, assembly, and disassembly facilities (RMAD and EMAD [Engine Maintenance, Assembly, and Disassembly]); a Control Point complex; an administrative area complex; and a radioactive materials storage area. 
Three separate, low-altitude, aerial surveys were conducted in this area. The boundaries of the first two survey regions encompassed the sites of the NRDS Test Cell A and Test Cell C reactor test stands. The boundary of the third survey region encompassed the RMAD facility.

\subsection{AERIAL SURVEY PLAN}

The low-altitude, aerial radiological surveys were flown using either a Messerschmitt-Bolkow-Blohm (MBB) BO-105 or a Bell-412 helicopter at a nominal ground speed of 40 knots (21 meters per second $[\mathrm{m} / \mathrm{s}])$, at a nominal altitude of 15 meters $(\mathrm{m})(50$-foot [ft]) above ground level (AGL), and along a set of parallel flight lines spaced $23 \mathrm{~m}(75 \mathrm{ft})$ apart. The aerial data were scaled to overlay on a U.S. Geological Survey topographic map of each survey region.

To ensure the integrity of the data and to monitor and correct variations in the measured background radiation due to radon, cosmic rays, and the aircraft, repeated measurements were made over a fixed, land test line before and after each flight. Based on the survey parameters cited in Appendix A, the lowaltitude, aerial surveys provided 100 percent coverage for each survey region.

\subsection{AERIAL RADIOLOGICAL SURVEY EQUIPMENT}

Standard aerial radiological survey techniques ${ }^{4}$ developed for large-area, gamma radiation surveys were used. The survey methodology has been successfully applied to more than 300 individual surveys at various locations beginning in the late 1960s.

The low-altitude, aerial radiological surveys were conducted using the RSL's Aerial Measuring System that included either a MBB BO-105 or Bell-412 helicopter; a Radiation and Environmental Data Acquisition and Recorder, Version IV or V (REDAR IV or V); and a Real-Time Differential Global Positioning System (RDGPS).

\subsection{Detector Pods}

The helicopter was equipped with two, large detector pods mounted on the sides of the landing skids. For the MBB BO-105 helicopter system, each pod contained four 2- $\times 4-\times 16$-inch thallium-activated sodium iodide, $\mathrm{NaI}(\mathrm{T} l)$, gamma-ray scintillation detectors. For the Bell-412 helicopter system, each pod contained a maximum of six $2-\times 4-\times 16$-inch $\mathrm{NaI}(\mathrm{T} l)$ detectors. The aerial results presented and discussed in this report have all been normalized to a 12-detector count rate.

The signal from each detector was calibrated using sodium-22 $\left({ }^{22} \mathrm{Na}\right)$ and ${ }^{241} \mathrm{Am}$ gamma-check sources. Normalized outputs from each of the detectors were combined in a summing amplifier, and the signal was adjusted in the analog-to-digital converter so that the calibration photopeaks appeared in preselected channels in one of the REDAR multichannel analyzers (MCAs). In addition, the calibrated output from only one of the detectors was fed to a separate MCA to provide increased dynamic range when viewing higher-radiation areas.

\subsection{REDAR System}

Data were acquired using either the REDAR IV or REDAR V system. Both systems were designed for use in aircraft. The REDAR IV is a portable, real-time multi-microprocessor, and data acquisition and 
analysis system. The REDAR IV system runs multiple, dedicated processors and operating systems including two 1024-channel MCAs. All data are acquired in 1-second increments and recorded to magnetic tape cartridges once every 4 seconds. The REDAR V is a portable, real-time, UNIX-based multi-processor, data collection instrument. The REDAR V runs multiple, dedicated processors and operating systems including four 4096-channel MCAs. All data are acquired in 1-second increments and stored to hard drives.

The typical data collected by the REDAR systems include two (REDAR IV) or four (REDAR V) 1024-channel gamma energy spectra, ambient air temperature, absolute barometric pressure, and aircraft altitude and position. This information can be displayed in real-time while in flight.

\subsection{Helicopter Positioning}

The position of the helicopter was established by using two systems: an RDGPS and a radar altimeter. The RDGPS is an OmniStar 3000L (space-based L-band) navigational system that provides continuous positional information accurate to $\pm 3 \mathrm{~m}(10 \mathrm{ft})$ using a minimum of 4 of the 24 Global Positioning System (GPS) satellites orbiting the earth at very high altitudes. The radar altimeter determines the altitude by measuring the round-trip propagation time of a radar signal reflected off the ground. The accuracy of the radar altimeter is \pm 2 percent or $2 \mathrm{ft}$, whichever is larger.

\subsection{Data Processing}

Data processing was performed by using a computer analysis laboratory system located at the RSL in Las Vegas, Nevada. Standard techniques for analyzing the survey data were used. Activity or count rates due to the nonnaturally occurring gamma sources of radiation (i.e., man-made radioactivity) or the contributions from a single isotope, namely ${ }^{241} \mathrm{Am}$, were determined through differences between the total counts in appropriate gamma energy spectral windows (Appendix B).

For the man-made activity, a two-window stripping method was employed. This method assumed that the count rates from the man-made radionuclides could be determined from the sum of the gross counts in the man-made gamma energy source window (38-1394 keV energy range) minus a scaled background contribution (1394-3026 keV energy range). The man-made gross count (MMGC) algorithm has been found to be sensitive to low levels of man-made radiation even in the presence of large variations in the natural background. It should be noted that in areas exhibiting excess concentrations of natural potassium, uranium, and/or thorium, the ratio of the low-energy to high-energy gamma rays may be different even though the gamma rays are emitted by naturally occurring radionuclides. This is also true for areas where the aircraft's altitude changes significantly from the planned altitude. In both such cases, the MMGC algorithm may generate a set of "false positive" anomalies on the MMGC contour map.

For the ${ }^{241}$ Am activity, a three-window stripping method was employed, which used a scaled background window (the sum of the gross counts in the 38-50 keV and 70-82 keV energy ranges) on each side of the ${ }^{241} \mathrm{Am}$ photopeak energy source window (50-70 keV energy range), instead of a single-scaled background window as was used in extracting the MMGC activity. The three-window algorithm is very useful in extracting low-energy photopeak counts where the shape of the Compton-scatter contributions from other isotopes is changing significantly. It should be noted that in areas where the aircraft's altitude changes significantly from the planned altitude and/or areas exhibiting excess concentrations of europium-152 $\left({ }^{152} \mathrm{Eu}\right)$, a set of "false positive" anomalies may be generated on the ${ }^{241} \mathrm{Am}$ contour map. Once a region-of-interest (ROI) (i.e., elevated ${ }^{241} \mathrm{Am}$ or man-made activity) has been identified, a detailed analysis is conducted to ascertain which radionuclides are present. Identification of the radionuclides is accomplished by examining the background-subtracted or net gamma energy spectra collected over the 
ROI. A net gamma energy spectrum is the resultant spectrum when the natural component has been removed. It should be noted that none of the net gamma energy spectra will be presented in this report. More detailed information pertaining to the extraction methods that were used to process the aerial data (i.e., gross count method, MMGC method, and the two- or three-window isotopic extraction algorithm method) can be found in separate publications. ${ }^{4,5}$

\subsection{RESULTS}

The three-window isotopic extraction algorithm method was used to analyze the aerial data for the ${ }^{241} \mathrm{Am}$ activity. For those regions where the detected radioactivity was not directly attributable to the presence of ${ }^{241} \mathrm{Am}$, the MMGC algorithm method was employed. The results of the ${ }^{241} \mathrm{Am}$ and/or MMGC analyses are presented as a contour map (color-coded contours with designators) superimposed on a U.S. Geological Survey topographic map for each survey region. The levels of ${ }^{241} \mathrm{Am}$ and/or man-made activity are shown in counts per second (cps) and are representative of the intensity of the detected radioactive material(s).

In the discussion that follows, a specific nuclear test or safety experiment may be described to provide background information to the observed radionuclide activity (e.g., ROI \#). In such cases, most of the nuclear test information shown in parentheses is taken from the United States Nuclear Tests. ${ }^{3}$ The nuclear information shown is the location designator (e.g., T3V), the test date, the test type (shaft, surface, or tower), and the device yield range, which is the total effective energy released and is cited in tons or kilotons.

It should be noted that the aerial data collected prior to the June 1999 surveys were unable to achieve the same lower level of minimum detectable activity (MDA) as detected in 1999 (i.e., 150 versus 70 cps for the ${ }^{241} \mathrm{Am}$ activity). The reason for the higher MDA level for those earlier surveys (Littler Feller I and II and NTS Area 9 sites) where an array of less than 8 detectors was flown (i.e., 1 or 4 detectors, respectively) can be attributed to poor detector count rate statistics. For the NTS Areas 3 and 8 surveys where an array of 8 and 9 detectors was flown, the reason for the higher MDA level is not known, but may be attributed to the general composition (e.g., soil density, elevation, geologic features and types, etc.) of those survey regions.

\subsection{Area 3}

The boundary of the low-altitude, aerial survey region in this area encompassed the Area 3 RWMS and the sites of the Humboldt nuclear weapons-related test, the Pike nuclear weapons-related test, and the Chavez and Otero safety experiments. The survey was flown in December 1996 using an MBB BO-105 helicopter, the REDAR IV system, and an array of eight $\mathrm{NaI}(\mathrm{T} l)$ detectors. The results of the aerial data have been normalized to a 12-detector-count rate.

As shown in Figure 1, elevated levels of ${ }^{241} \mathrm{Am}$ activity were detected at ten ROI locations:

\# The northwestern area hosted the Pascal-A (ROI \#1; U-3j; July 26, 1957; shaft; slight yield), the Pascal-B (ROI \#2; August 27, 1957; shaft; slight yield), and the Otero (ROI \#3; September 12, 1958; shaft; 38-ton yield) safety experiments.

\# ROI \#4 is located on the northern border of the Area 3 RWMS and overlies the location of the Humboldt (T3V; October 29, 1958; tower; 7.8-ton yield) weapons-related test. 
\# In the northeastern area, ROI \#5 overlies the location of the Pike (U-3cy; March 13, 1964; shaft; less than 20-kiloton yield) weapons-related test. The ${ }^{241} \mathrm{Am}$ analyses of this ROI revealed three distinct locations within a larger region of slightly lower contamination.

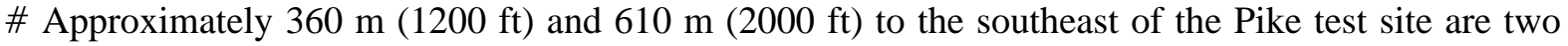
elevated regions of contamination, ROIs \#6 and \#7, respectively. ROI \#7 was also detected during the 1994 survey. ${ }^{1}$ Neither ROI can be directly attributed to any known nuclear test.

\# ROI \#8 overlies the location of the Chavez (T3U; October 27, 1958; tower; 0.6-ton yield) and Coulomb-C (S3I; December 9, 1957; surface; 500-ton yield) safety experiments. The resulting ${ }^{241} \mathrm{Am}$ plume extends southward for approximately $360 \mathrm{~m}(1200 \mathrm{ft})$.

\# ROI \#9 resides along the western border of the Area 3 RWMS and overlies the locations of the Catron (T3T; October 24, 1958; tower; 21-ton yield) and Coulomb-B (S3G; September 6, 1957; surface; 300-ton yield) safety experiments.

\# ROI \#10 resides along the southern border of the Area 3 RWMS and overlies the location of the Gerbil (U3bp; March 29, 1963; shaft; low yield) weapons-related test.

\# The rest of the small regions of ${ }^{241} \mathrm{Am}$ activity are probably statistical fluctuations in the count rate of the three-window isotopic extraction algorithm.

\subsection{Area 5}

The boundary of the low-altitude, aerial survey region in this area encompassed the GMX Project Area. This survey was flown in June 1999 using a Bell-412 helicopter, the REDAR V system, and an array of $12 \mathrm{NaI}(\mathrm{T} l)$ detectors.

As shown in Figure 2, elevated levels of ${ }^{241} \mathrm{Am}$ activity were detected near the center of the survey region. The ${ }^{241} \mathrm{Am}$ plume proceeds in a north-northeasterly direction and is approximately $610 \mathrm{~m}$ (2000 ft) in length. Although a review of the history of this area had considered the source of the 24 experiments to be at one location, examination of the ${ }^{241} \mathrm{Am}$ contour map revealed a second area (ROI \#2) of lower activity approximately $120 \mathrm{~m}$ (400 ft) south of the highest-activity area (ROI\#1). Only

${ }^{241} \mathrm{Am}$ radioactivity was detected at the GMX site.

\subsection{Area 8}

The boundary of the low-altitude, aerial survey region in this area encompassed the sites of the Ceres, Oberon, and Titania safety experiments. The survey was flown in July 1997 using a Bell-412 helicopter, the REDAR V system, and an array of $12 \mathrm{NaI}(\mathrm{T} l)$ detectors.

As shown in Figure 3, elevated levels of ${ }^{241}$ Am activity were detected at four ROI locations:

\# The northernmost plume hosted three tests: the Oberon (ROI \#1; T8A; October 22, 1958; tower; 0 yield) and Ceres (ROI \#2; T8B; October 26, 1958; tower; 0.7-ton yield) safety experiments, and the Mudpack (ROI \#3; U-10n; December 16, 1964; 2.7-kiloton yield) weapons effects test. The ${ }^{241} \mathrm{Am}$ plume in this region extends and continues in a northwesterly direction beyond the boundary of the survey region toward the Smoky Hills. 


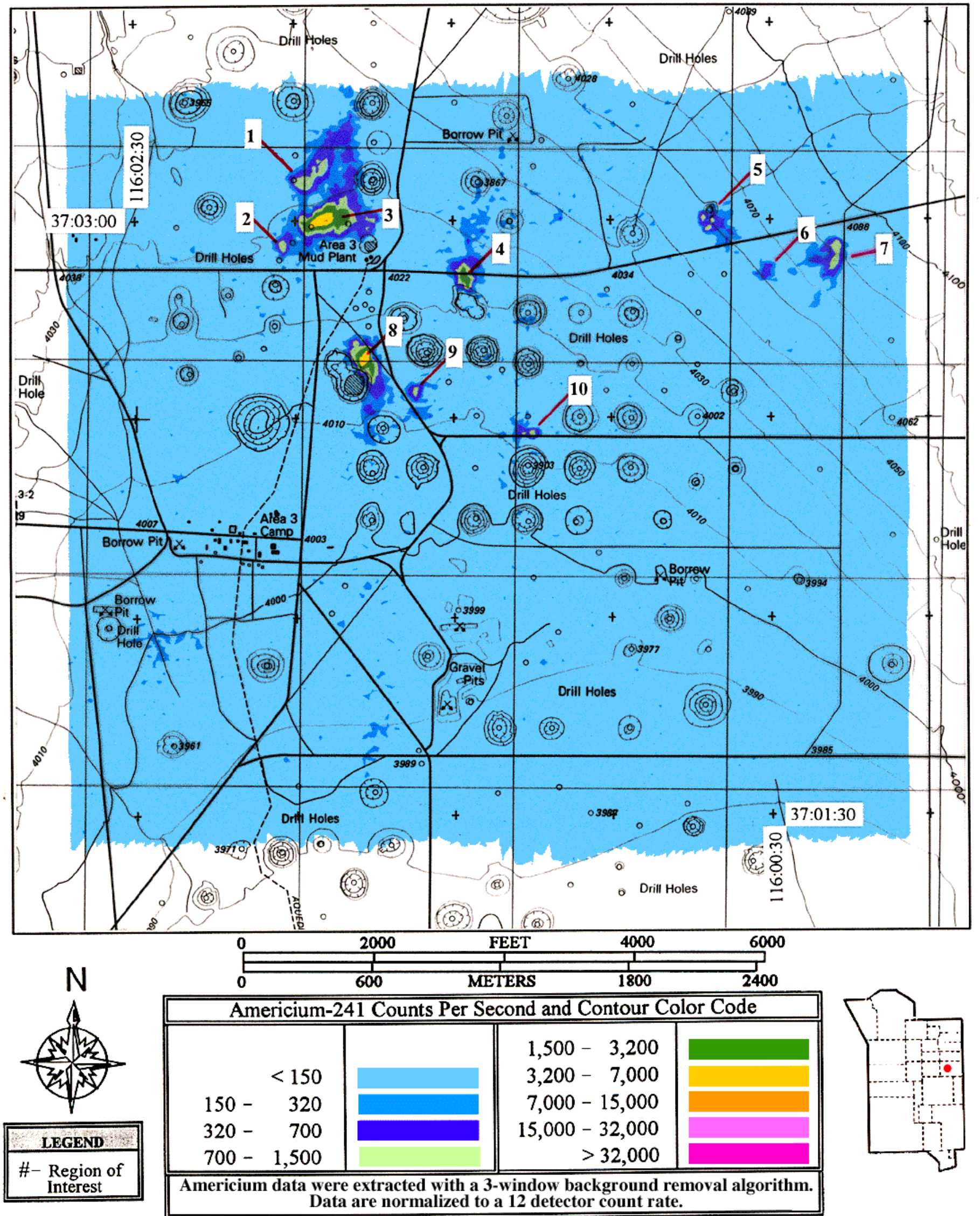

Figure 1. Americium-241 Contour Map of the NTS Area 3 50-Foot Altitude, 75-Foot-Line Spacing, 40-Knot-Ground Speed

MBB BO- 105 Helicopter with 8 (2- x 4- x 1 -inch) Sodium Iodide Detectors Dates of Survey: December 2 to 6.1996 

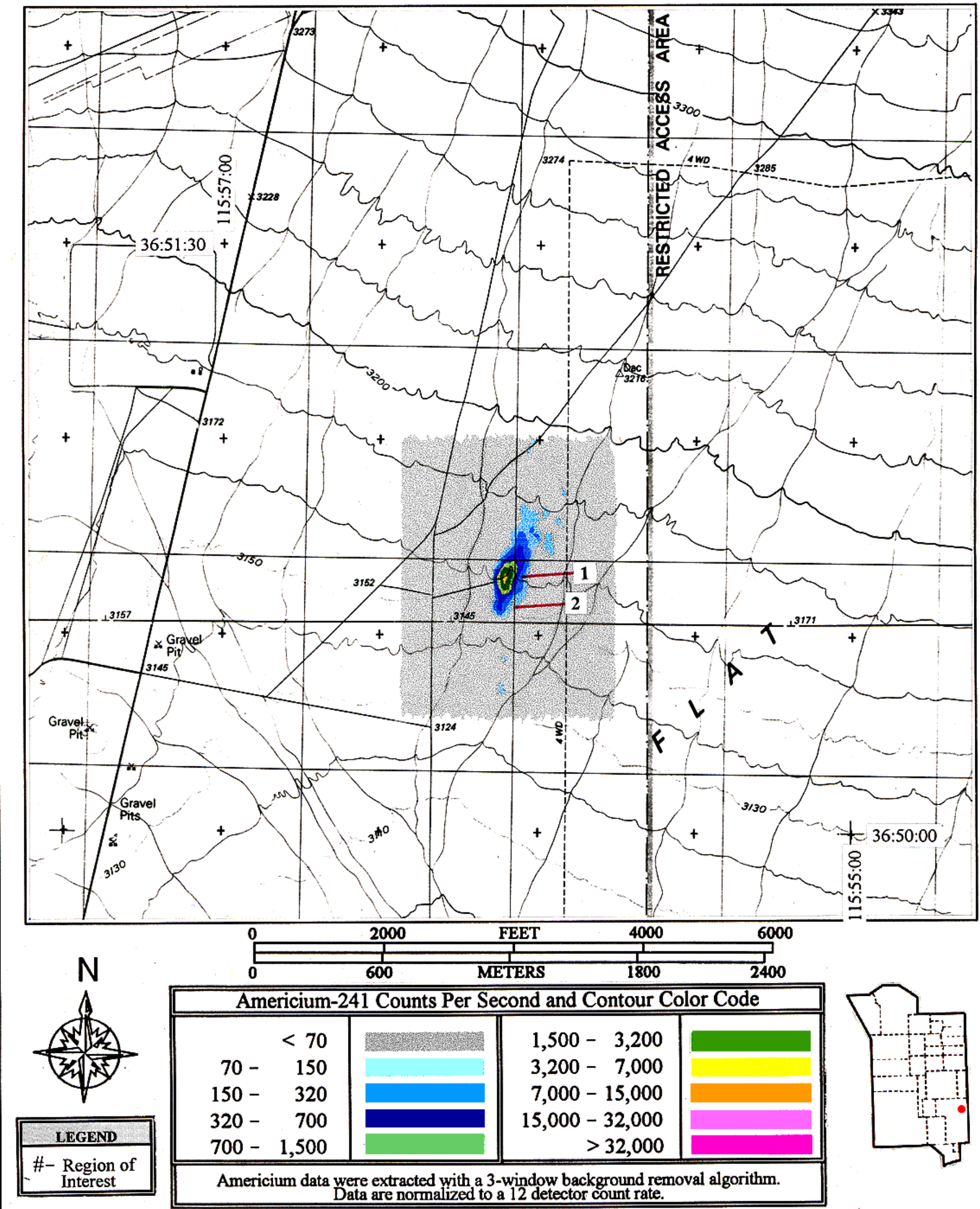

Figure 2. Americium-241 Contour Map of the GMX Project Area in the NTS Area 5 50-Foot Altitude, 75-Foot-Line Spacing, 40-Knot-Ground Speed

Bell-412 Helicopter with 12 (2- x 4- x 16-inch) Sodium Iodide Detectors 

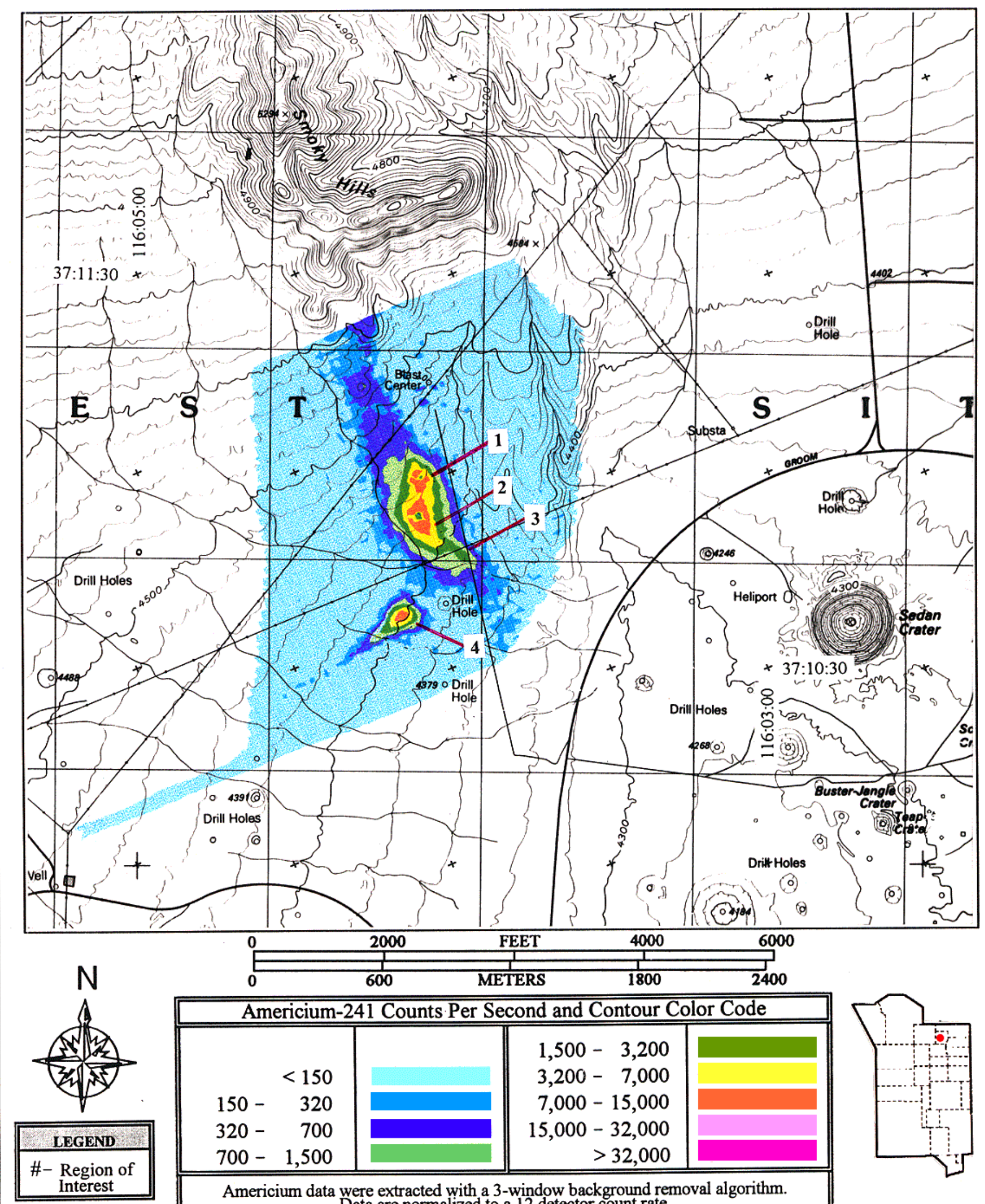

Americium data were extracted with a 3-window background removal algorithm.

Data are normalized to a 12 detector count rate.

Figure 3. Americium-241 Contour Map of the NTS Area 8 50-Foot Altitude, 75-Foot-Line Spacing, 40-Knot-Ground Speed

Bell-412 Helicopter with 12 (2- x 4- x 16-inch) Sodium Iodide Detectors 
\# The highest ${ }^{241} \mathrm{Am}$ activity level of the southernmost plume overlies the location of the Titania (ROI \#4, T8C; October 30, 1958; tower; 0.2-ton yield) safety experiment. The ${ }^{241}$ Am plume in this region extends and continues in a southwesterly direction for approximately $390 \mathrm{~m}(1300 \mathrm{ft})$.

\# The rest of the small regions of ${ }^{241} \mathrm{Am}$ activity are probably statistical fluctuations.

\subsection{Area 9}

The boundary of the low-altitude, aerial survey region in this area encompassed the sites of the Mazama and Post nuclear weapons-related tests, and the sites of the Juno and Vesta safety experiments. The survey was flown in May 1998 using a Bell-412 helicopter, the REDAR V system, and an array of 4 $\mathrm{NaI}(\mathrm{T} l)$ detectors. The results of the aerial data have been normalized to a 12-detector-count rate.

As shown in Figure 4, elevated levels of ${ }^{241}$ Am activity were detected at seven ROI locations:

\# ROI \#1 overlies the location of the Mazama site (T9D; October 29, 1958; tower; 0 yield).

\# The largest-contour area reveals two distinct plume patterns. The first plume pattern centers around the site of the Juno (ROI \#2; S9F; October 24, 1958; 1.7-ton yield) safety experiment and extends in a southwesterly direction for approximately $760 \mathrm{~m}(2500 \mathrm{ft})$ encompassing the site of the Kootanai (ROI \#4; April 24, 1963; shaft; low yield) weapons-related test. The second plume pattern centers around the sites (ROI \#5) of the Post (T9C; April 9, 1955; tower; 2-kiloton yield) weapons-related test and the Vesta (S9E; October 17, 1958; surface; 24-ton yield) safety experiment. This second plume then continues to extend in a northerly direction for approximately $520 \mathrm{~m}(1700 \mathrm{ft})$ and encompasses the sites of the Hoosic (ROI \#6; U-9j; March 28, 1962; shaft; 3.4-kiloton yield) and the Campos (ROI \#7; U-9cp; February 13, 1978; shaft; less than 20-kiloton yield) weapons-related tests.

\# The elevated ${ }^{241} \mathrm{Am}$ activity depicted at ROI \#3 is approximately $60 \mathrm{~m}(200 \mathrm{ft})$ south of the Juno site, and this activity does not overlie any of the known nuclear test locations.

\subsection{Area 11}

The boundary of the low-altitude, aerial survey region in this area encompassed the four Project 56 safety experiments (Numbers 1 to 4 ) plus a portion of the Plutonium Valley. The northern boundary of the survey region is located approximately 6.8 kilometers (4.2 mile) from the Project 56 Site Number 1 (ROI \#1) location. This survey was flown in June 1999 using a Bell-412 helicopter, the REDAR V system, and an array of $12 \mathrm{NaI}(\mathrm{T} l)$ detectors.

As shown in Figure 5, elevated levels of ${ }^{241}$ Am activity were detected at seven distinct areas within the southern portion of the survey region plus an area of lower activity was observed extending northerly through the Plutonium Valley.

\# ROI \#1 is a low-activity region that overlies the location of the Project 56 Site Number 1 (S11A; November 1, 1955; surface; 0 yield). This site exhibited only uranium-235 activity and no ${ }^{241} \mathrm{Am}$ activity in the 1982 survey. $^{6}$

\# ROI \#2 overlies the location of the Project 56 Site Number 2 (S11B; November 3, 1955; surface; 0 yield), where the detected ${ }^{241} \mathrm{Am}$ activity is more spread out with a small plume extending in a northwesterly direction toward the Project 56 Site Number 1. 


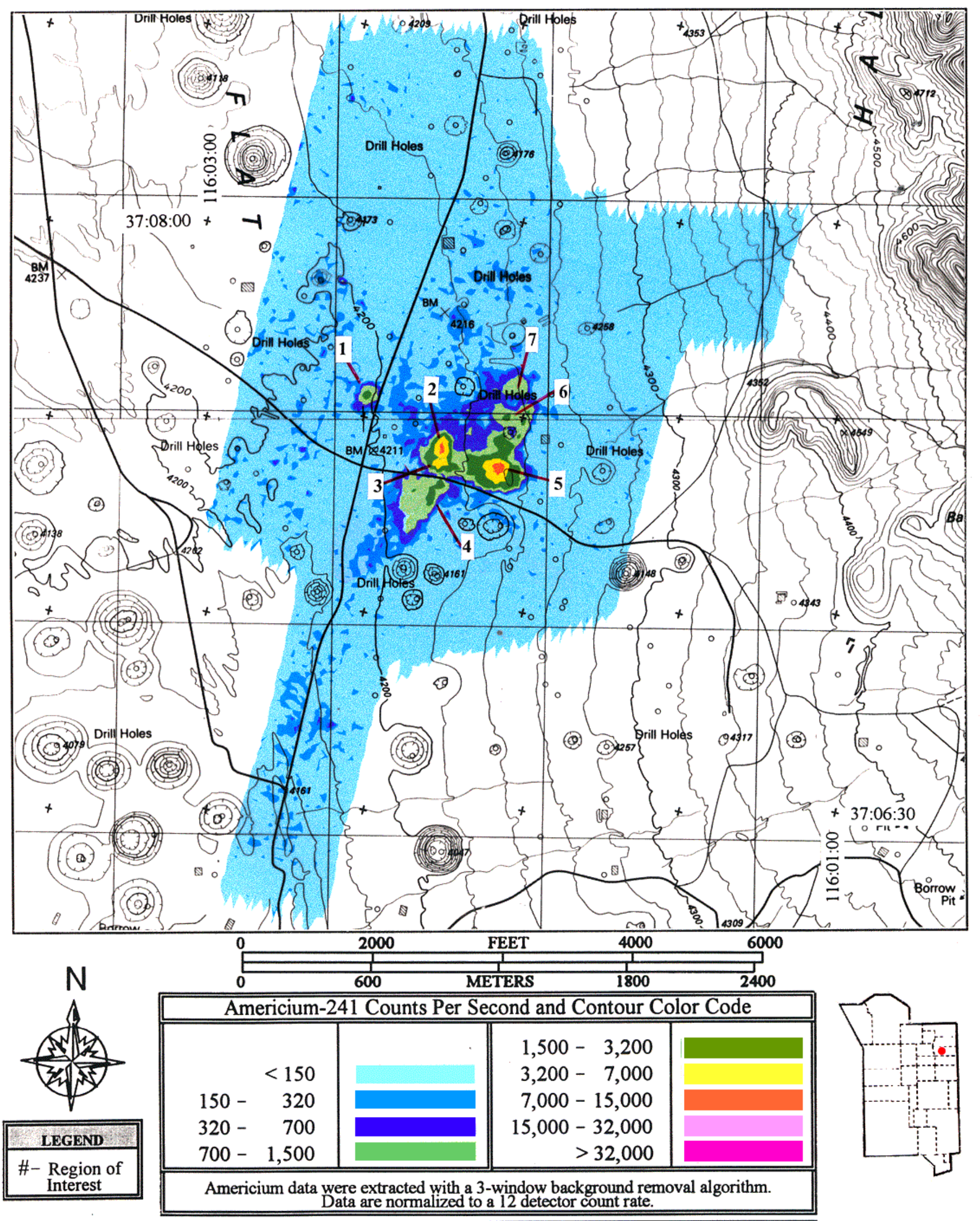

(19)

Figure 4. Americium-241 Contour Map of the NTS Area 9 50-Foot Altitude, 75-Foot-Line Spacing, 40-Knot-Ground Speed

Bell-412 Helicopter with 4 (2- $x$ 4- x 16-inch) Sodium Iodide Detectors 


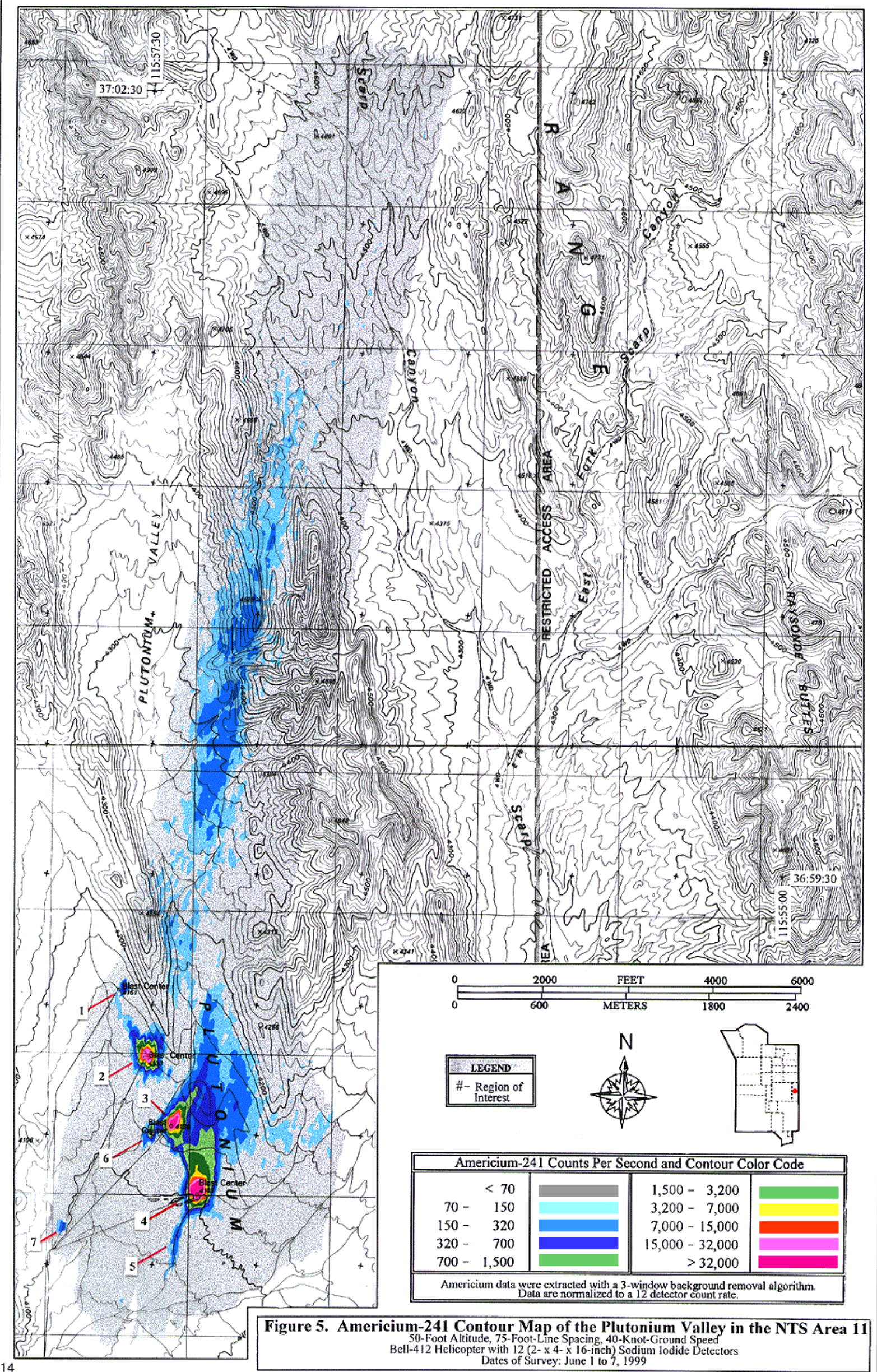


\# The largest contour area contains two separate test sites: ROI \#3 overlies the location of the Project 56 Site Number 3 (S11C; November 5, 1955; surface; 0 yield) and ROI \#4 overlies the location of the Project 56 Site Number 4 (S11D; January 18, 1956; surface; very slight yield).

\# The ${ }^{241}$ Am activity emanating from Site Number 4 extends in three directions. One plume (ROI \#5) extends south-southwesterly along a streambed and continues for approximately $640 \mathrm{~m}(2100 \mathrm{ft})$. A second plume extends in a northwesterly direction and joins with the plume emanating around Site Number 3. The third plume extends northerly and again joins with the plume emanating from Site Number 3. This combined plume then continues for approximately $520 \mathrm{~m}(1700 \mathrm{ft})$ in a north-northeasterly direction.

\# The ${ }^{241}$ Am activity emanating from Site Number 3 also extends in three directions. Two of the plumes extend and join with the plumes emanating from Site Number 4. However, the third plume (ROI \#6) extends southwesterly along a streambed for approximately $150 \mathrm{~m}(500 \mathrm{ft})$.

\# A small isolated area of low activity (ROI \#7) was detected at the southwestern corner of the survey region, the activity at this location is real and not a statistical fluctuation. A net gamma energy spectrum of this area revealed the presence of only ${ }^{241} \mathrm{Am}$.

\subsection{Area 18}

Three independent, low-altitude, aerial survey regions were flown in this area. The boundaries of the first two survey regions encompassed the sites of the Little Feller I and II nuclear weapons-effects tests. These two survey regions were flown in June 1998 using a Bell-412 helicopter, the REDAR V system, and only one $\mathrm{NaI}(\mathrm{T} l)$ detector. The results of the aerial data for the Little Feller surveys have been normalized to a 12-detector-count rate.

The boundary of the third survey region encompassed the site of the Danny Boy nuclear weapons-effects test. This survey was flown in June 1999 using a Bell-412 helicopter, the REDAR V system, and an array of $12 \mathrm{NaI}(\mathrm{T} l)$ detectors.

Figure 6 shows the elevated levels of ${ }^{241} \mathrm{Am}$ activity emanating from the sites of the Little Feller I (ROI \#1; S18; July 17, 1962; surface; low yield) and the Little Feller II (ROI \#2; S18; July 7, 1962; surface; low yield) weapon-effects tests. Both sets of plumes followed a similar dispersal pattern. Each plume proceeded in a northwesterly direction for approximately $900 \mathrm{~m}(3000 \mathrm{ft})$ prior to turning north. No other nuclear tests were reported as being conducted in this area.

Figure 7 shows the elevated ${ }^{241}$ Am activity emanating from the Danny Boy weapons-effects test that occurred on March 5, 1962, and was buried in a shallow hole to produce a crater. It had a published yield of 430 tons.

\subsection{Area 25}

Three independent, low-altitude, aerial survey regions were flown in this area. The boundaries of the first two survey regions encompassed the NRDS Test Cell A and Test Cell $\mathrm{C}$ reactor test stands. The boundary of the third survey region encompassed the site of the RMAD facility. These three survey regions were flown in June 1999 using a Bell-412 helicopter, the REDAR V system, and an array of $12 \mathrm{NaI}(\mathrm{T} l)$ detectors. 


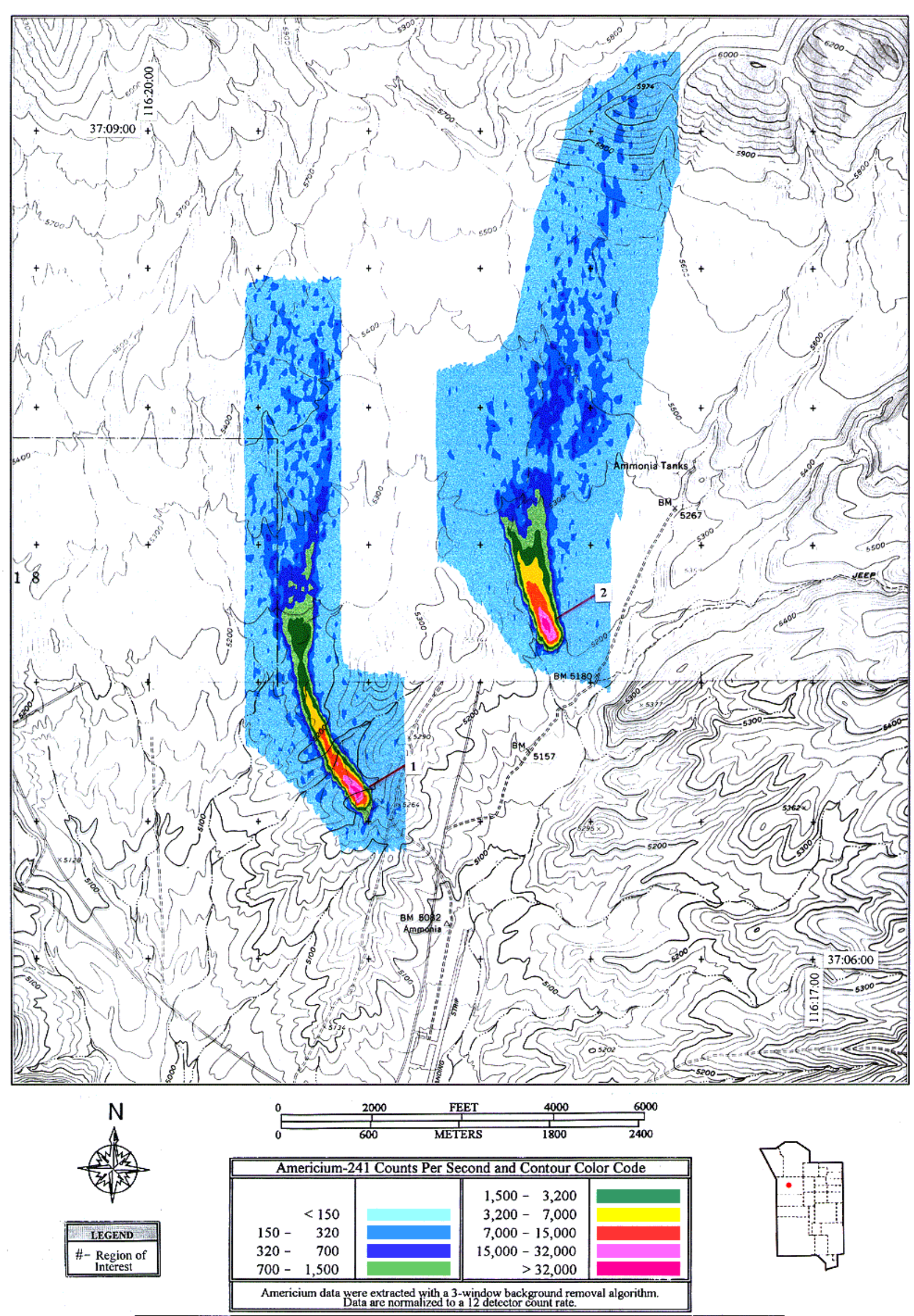

Figure 6. Americium-241 Contour Map of the Little Feller Sites in the NTS Area 18

Bell-412 Helicopter with One $(2-x 4-\times 16-$ inch $)$ Sodium Iodide Detector 


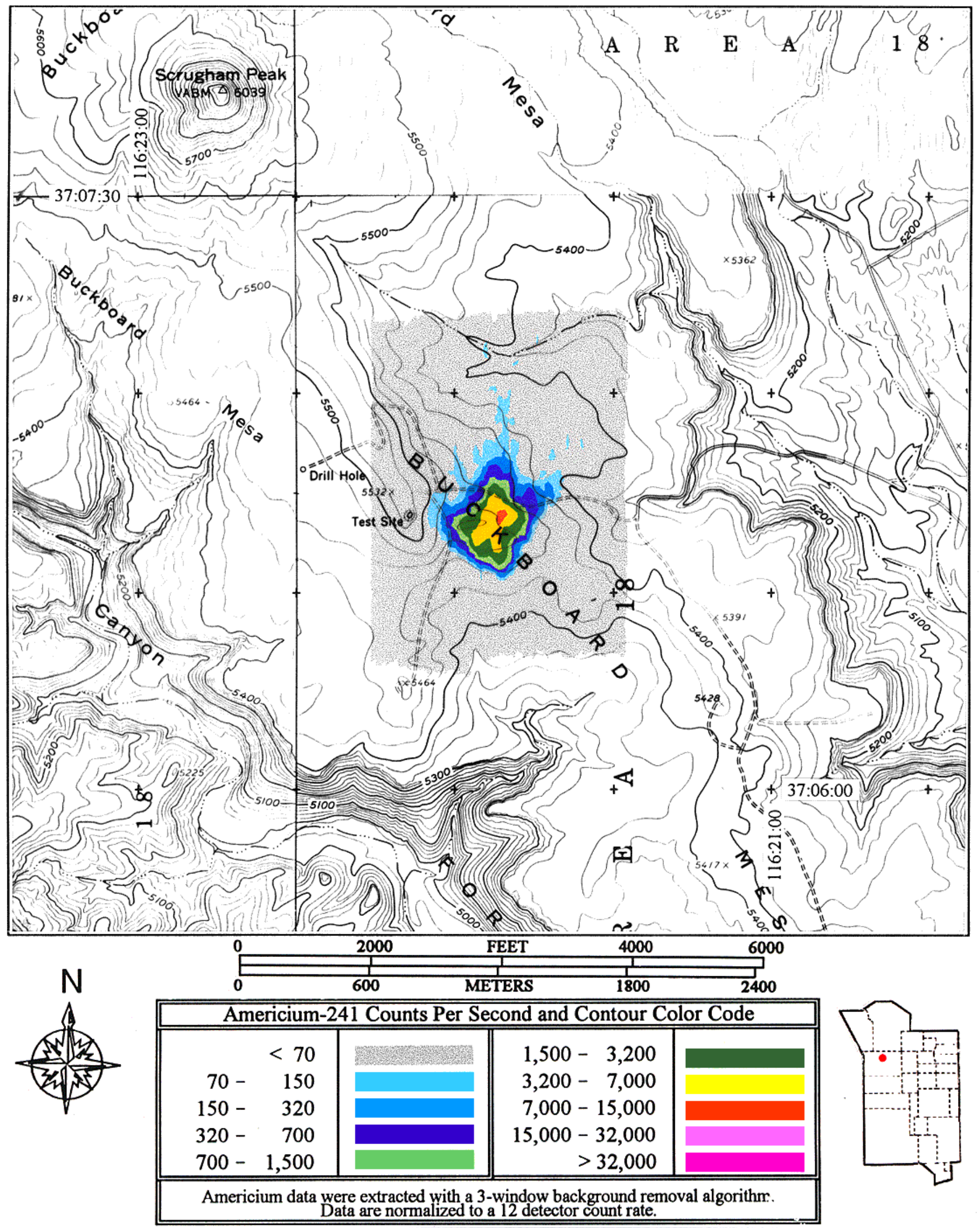

Figure 7. Americium-241 Contour Map of the Danny Boy Site in the NTS Area 18 50-Foot Altitude, 75-Foot-Line Spacing, 40-Knot-Ground Speed

Bell-412 Helicopter with 12 (2- x 4- x 16-inch) Sodium Iodide Detectors Dates of Survey: June 15 to 16,1999 
Figure 8 shows the elevated levels of the MMGC activity emanating from the survey regions located in Area 25 . No ${ }^{241} \mathrm{Am}$ activity, except for statistical fluctuations, had been detected. Hence, only the MMGC activity contour map will be presented.

\# Two distinct areas (ROI \#1 and \#2) of the MMGC activity were detected within the NRDS Test Cell $\mathrm{C}$ complex. The net gamma energy spectra of these two areas revealed the presence of cesium-137 $\left({ }^{137} \mathrm{Cs}\right)$ and europium-152 $\left({ }^{152} \mathrm{Eu}\right)$.

\# ROI \#3 overlies the facilities residing within the NRDS Test Cell A complex. A net gamma energy spectra of this area revealed the presence of ${ }^{137} \mathrm{Cs}$ and ${ }^{152} \mathrm{Eu}$.

\# Four distinct areas (ROIs \#4 through \#7) of MMGC activity were detected within the RMAD complex. The net gamma energy spectra of these four areas revealed the presence of only ${ }^{137} \mathrm{Cs}$.

\subsection{CONCLUSION}

Eleven low-altitude, aerial radiological surveys of selected regions within Areas 3, 5, 8, 9, 11, 18, and 25 of the NTS were conducted during the period from December 1996 through June 1999. The lowaltitude, surveys were flown at a nominal altitude of $15 \mathrm{~m}$ AGL along a set of parallel flight lines spaced 23 m apart.

Americium-241 activity was detected within 8 of the 11 regions. The three survey regions where no

${ }^{241} \mathrm{Am}$ activity was detected were in the inactive NRDS complex in Area 25, which encompassed the Test Cell $\mathrm{A}$ and Test Cell $\mathrm{C}$ complexes and the RMAD facility. 


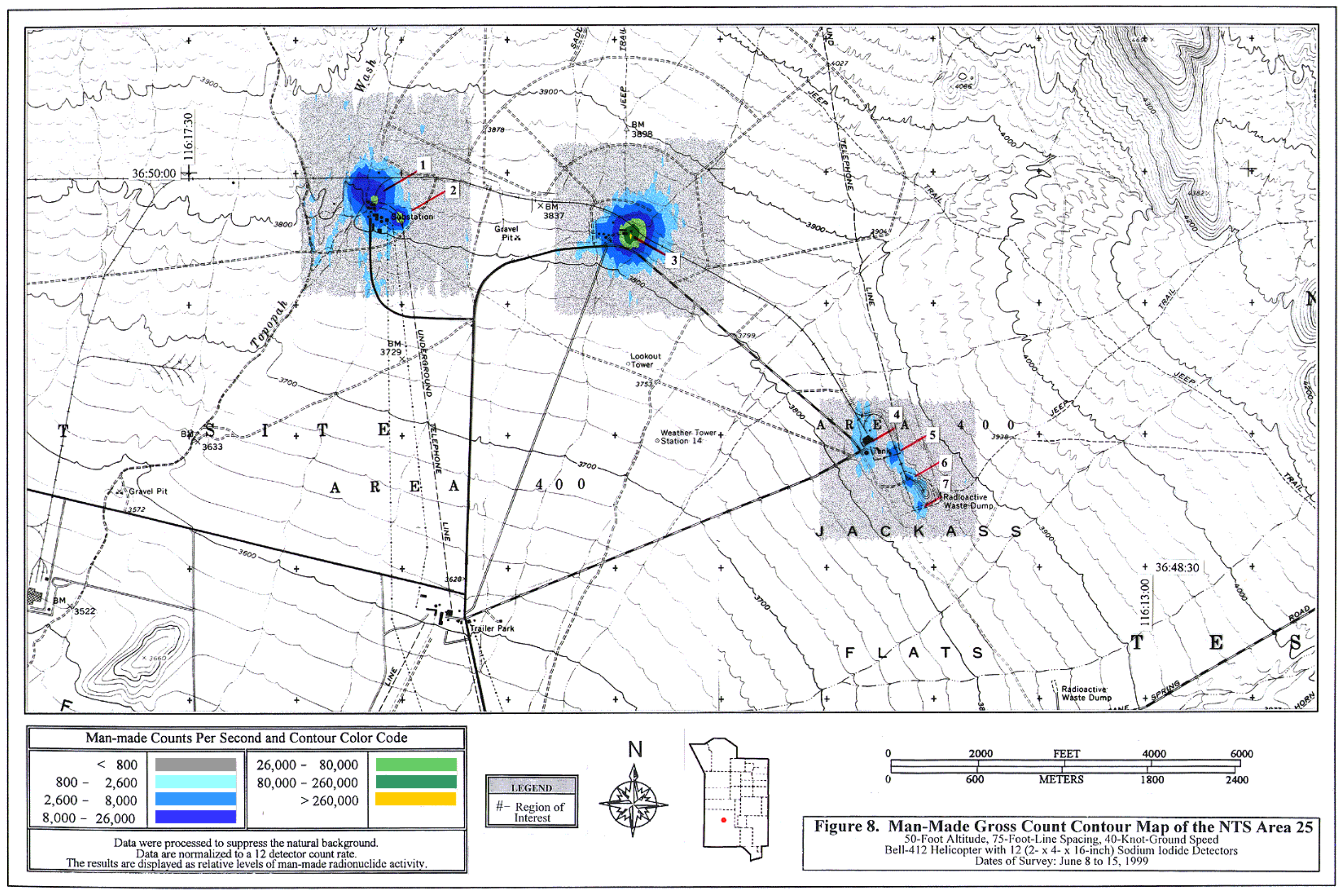




\subsection{REFERENCES}

1. Hendricks, T.J; Riedhauser, S.R. An Aerial Radiological Survey of the Nevada Test Site. Report No. DOE/NV/11718-324, 1999; Bechtel Nevada, Las Vegas, Nevada.

2. Environmental Impact Statement. U.S. Department of Energy, Web Site (http://www.nv.doe.gov/news\&pubs/publications/envm/eis/document/ch4.htm); Chapter 4; May 1999.

3. United States Nuclear Tests: July 1945 through September 1992. Report No. DOE/NV-209, Rev. 14, 1994; U.S. Department of Energy, Las Vegas, Nevada.

4. Proctor, A.E. Aerial Radiological Surveys. Report No. DOE/NV/11718-127, 1997; Bechtel Nevada, Las Vegas, Nevada.

5. Hendricks, T.J. "Radiation and Environmental Data Analysis Computer (REDAC) Hardware, Software, and Analysis Procedures," in Remote Sensing Technology, Proceedings of a Symposium on Remote Sensing Technology in Support of the United States Department of Energy, 23-25 February 1983. Report No. EGG-10282-1057, 1985; EG\&G, Las Vegas, Nevada.

6. Clark, H.W. An Aerial Radiological Survey of Area 11 Nevada Test Site. Report No. EGG-102821004, 1983; EG\&G, Las Vegas, Nevada. 


\section{APPENDIX A}

AERIAL SURVEY PARAMETERS

\section{GENERIC SURVEY PARAMETERS}

Survey Altitude

Average Ground Speed

$15 \mathrm{~m}(50 \mathrm{ft}) \mathrm{AGL}$

Survey Line Spacing

$21 \mathrm{~m} / \mathrm{s}$ (40 knots)

Navigation System

$23 \mathrm{~m}(75 \mathrm{ft})$

OmniStar 3000L DGPS System

(space-based L-band)

\section{NTS SURVEY REGION PARAMETERS}

\section{Area 3: Chavez, Humboldt, Otero, and Pike Nuclear Tests}

Survey Dates

$\mathrm{NaI}(\mathrm{T} l)$ Detector Array

Data Acquisition System

Aircraft

\section{Area 5: GMX Project Area}

Survey Date

$\mathrm{NaI}(\mathrm{T} l)$ Detector Array

Data Acquisition System

Aircraft
December 2 to 6,1996

Eight 2- $\times 4-\times 16$-inch logs

REDAR IV

MBB BO-105 Helicopter

(Tail Number: N70EG)

June 3, 1999

Twelve 2- × 4- × 16-inch logs

REDAR V

Bell-412 Helicopter

(Tail Number: N411DE)

July 24, 1997

Twelve $2-\times 4-\times 16$-inch logs

REDAR V

Bell-412 Helicopter

(Tail Number: N411DE)

\section{Area 9: Juno, Mazama, Post, and Vesta Nuclear Tests}

Survey Dates

$\mathrm{NaI}(\mathrm{T} l)$ Detector Array

Data Acquisition System

Aircraft
May 6 to 7, 1998

Four 2- $\times 4-\times 16$-inch logs

REDAR V

Bell-412 Helicopter

(Tail Number: N411DE)

\section{Area 11: Plutonium Valley (Project 56, Numbers 1, 2, 3, and 4)}

Survey Dates

$\mathrm{NaI}(\mathrm{T} l)$ Detector Array

Data Acquisition System

Aircraft
June 1 to 7,1999

Twelve 2- $\times 4-\times 16$-inch $\log s$

REDAR V

Bell-412 Helicopter

(Tail Number: N411DE) 


\section{Area 18: Danny Boy Nuclear Test}

Survey Dates

$\mathrm{NaI}(\mathrm{T} l)$ Detector Array

Data Acquisition System

Aircraft
June 15 to 16,1999

Twelve 2- × 4- ×16-inch logs

REDAR V

Bell-412 Helicopter

(Tail Number: N411DE)

Area 18: Little Feller I and II Nuclear Tests

Survey Dates

$\mathrm{NaI}(\mathrm{T} l)$ Detector Array

Data Acquisition System

Aircraft
June 16 to 19,1998

One 2- $\times$ 4- $\times$ 16-inch log

REDAR V

Bell-412 Helicopter

(Tail Number: N411DE)

\section{Area 25: NRDS Test Cell A, NRDS Test Cell C, and RMAD Sites}

Survey Dates

$\mathrm{NaI}(\mathrm{T} l)$ Detector Array

Data Acquisition System

Aircraft
June 8 to 15,1999

Twelve $2-\times 4-\times 16$-inch logs

REDAR V

Bell-412 Helicopter

(Tail Number: N411DE) 


\section{APPENDIX B \\ DATA ANALYSIS PARAMETERS}

\section{Man-Made Gross Count Rate (MMGC)}

Source Energy Window

Background Energy Window

38-1394 keV

$1394-3026 \mathrm{keV}$

\section{Americium-241Count Rate ( $\left.{ }^{241} \mathrm{Am}\right)$}

Source Energy Window

$50-70 \mathrm{keV}$

Background Energy Windows

Point-Source Conversion Factor

$38-50$ and $70-82 \mathrm{keV}$

Soil-Distribution Conversion Factor

$8.3 \mathrm{E}-02 \mathrm{cps} /(\mu \mathrm{Ci})$

$714 \mathrm{cps} /\left(\mu \mathrm{Ci} / \mathrm{m}^{2}\right)$ 
DOE/DP

J.A. Weidner, CDR USN

DOE/NSIC

R.S. Scott

T.A. Cooper

D.R. Elle

\section{BECHTEL NEVADA}

C.M. Bluitt

P.P. Guss
RSL-N

RSL-A
K.R. Lamison, Jr. RSL-N

R.J. Maurer RSL-A

J.T. Mitchell, Jr. LVAO

M.F. Mohar RSL-N

S.R. Riedhauser RSL-N

R.J. Vojtech RSL-A

A.J. Will RSL-N

(1)

OSTI

\section{RESOURCE CENTERS}

DOE/NV Public Reading Facility

RSL-Andrews

RSL-Nellis

TIRC

\footnotetext{
A SERIES OF LOW-ALTITUDE AERIAL RADIOLOGICAL SURVEYS OF SELECTED REGIONS WITHIN AREAS 3, 5, 8, 9, 11, 18, AND 25 OF THE NEVADA TEST SITE

CENTRAL NEVADA

DOE/NV/11718--362

SURVEY DATES

DECEMBER 2 TO 6, 1996

JULY 24, 1997

MAY 6 TO 7, 1998

JUNE 16 TO 19, 1998

JUNE 1 TO 16, 1999

REPORT DATE

DECEMBER 1999
} 